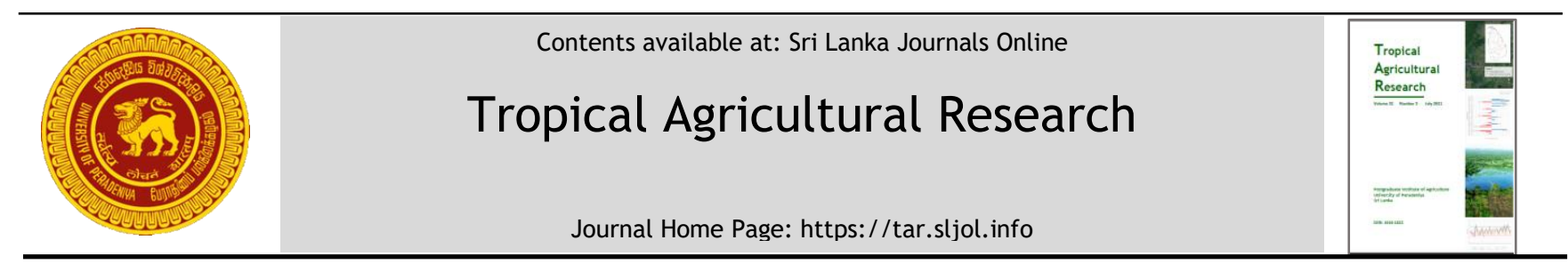

\title{
Growth Physiology and Crop Yields of Direct-seeded Rice under Diverse Input Systems in the Dry Zone of Sri Lanka
}

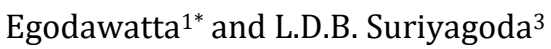 \\ ${ }^{1}$ Faculty of Agriculture, Rajarata University of Sri Lanka, Anuradhapura, Sri Lanka. \\ ${ }^{2}$ Department of Plant Sciences, University of Saskatchewan, Canada. \\ ${ }^{3}$ Faculty of Agriculture, University of Peradeniya, Peradeniya, Sri Lanka.
}

W.M.D.M. Wickramasinghe ${ }^{1}$, D.A.U.D. Devasinghe ${ }^{1}$, D.M.D. Dissanayake ${ }^{1}$, D.I.D.S. Benaragama ${ }^{2}$, W.C.P.

\section{ARTICLE INFO}

\section{Article history:}

Received: 14 August 2020

Revised version received: 10 January 2020

Accepted: 2 February 2021

Available online: 30 July 2021

\section{Keywords:}

Conventional

Integrated nutrient management

Leaf nitrogen

Organic

Rice

\section{Citation:}

Wickramasinghe, W.M.D.M., Devasinghe, D.A.U.D., Dissanayake, D.M.D., Benaragama, D.I.D.S., Egodawatta, W.C.P., and Suriyagoda, L.D.B. (2021). Growth physiology and crop yields of directseeded rice under diverse input systems in the Dry Zone of Sri Lanka. Tropical Agricultural Research, 32(3): 325-337.

DOI: http://doi.org/10.4038/tar.v32i3.8496

Wickramasinghe, W.M.D.M. https://orcid.org/0000-0001-7124-3868

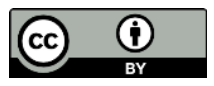

\footnotetext{
*Corresponding author: egowcp@gmail.com
}

\section{ABSTRACT}

The dynamics of organic and inorganic nutrient sources in diverse input systems can affect physiological processes of rice. Understanding these nutrient dynamics and their relation to final yields are important to devise optimum nutrient management strategies. This experiment was conducted to evaluate the relationships between nutrient availability from different sources, and growth physiology and crop yield of rice during 2019 Yala and 2019/20 Maha seasons. The Department of Agriculture (DOA) recommended inorganic fertilizer application (conventional system), 50\% of DOA recommended inorganic fertilizer with organic manure mixture (integrated system), and $100 \%$ organic manure mixture application (organic system) were used as three treatments. Organic manure mixture was added to equalize the nitrogen supply through DOA rate. The systems were arranged in a randomized complete block design with six replicates and Bg 300 rice variety was used. The conventional and integrated systems were similar, while the organic system was weak in canopy light interception, photosynthetic rate, and leaf chlorophyll content at panicle initiation and heading stages. The treatment effect was significant $(P<0.05)$ in 2019 Yala (dry season) but not in 2019/20 Maha (wet season). The correlations between leaf nitrogen concentration and yield were observed with respect to input systems. Most physiological parameters showed no robust correlation to biomass and crop yield. Crop yields were higher in the conventional and integrated systems compared to the organic system. However, the differences are expected to be narrowed down with the development of long-term nutrient status in the organic system as this study was conducted during the first year of the transition. 


\section{INTRODUCTION}

Global agriculture has transformed dramatically ever since the man started domesticating crops. The green revolution is one of the major milestones that transformed global crop production in recent history. Similar to many other countries the crop production technology in Sri Lanka at present descends from the green revolution model where crops are raised with synthetic inputs (Hazell, 2009). These systems are typically known as conventional agriculture. It aims to maximize the yield of a particular crop or set of crops, by using a significant amount of chemical inputs at the expense of environmental pollution and human health (Evenson and Gollin, 2003). Rice crop production in Sri Lanka is predominantly shaped by conventional agricultural practices. Higher dependency on synthetic fertilizer is common in most rice-based cropping systems, with a primary objective of achieving higher crop yields (Wimalawansa, 2014).

Injudicious use of synthetic fertilizers in rice production systems is now witnessing series of negative impacts on the environment (Bhakiyathu et al., 2005; Wickramasinghe, 2005; Seneviratne, 2009 and Kumar and Prakash, 2019). Ultimately, the contribution to global warming and the imbalance of ecological processes are undeniable (Rahman, 2015). Under this context, it is important to identify suitable means for maintaining soil and plant health without risking grain yield and food security (Dissanayake et al., 2014 and Rao et al., 2019). Besides well-known negative concerns of conventional agriculture, alternative systems are not popular due to the lower productivity. Many sustainable alternative strategies exist to overcome the negative effect of conventional agriculture systems globally (Wijebandara et al., 2008; Ekanayake, 2009 and Sirisena et al., 2016). Those alternative systems are not popular due to the lower productivity.

Organic and low input or integrated systems are widely practiced in alternative farming systems in most of the countries (Reganold and Wachter, 2016). These alternative systems are gaining momentum in many countries. However, still Sri Lankan farmers have been reluctant to adopt organic farming or low input integrated farming practices. The main reasons for the low level of adoption of alternative sustainable crop production systems could be due to the higher organic input demand, lower initial yields, and lower economic outcomes in transition from conventional to organic agriculture (Dabbert and Madden, 1986; Chen, 2006). Comparatively low crop yield during the transition period is the major problem in most of the alternative input systems (Yadav et al., 2000).

Since organic systems purely depend on organic nutrients sources, the quantity, and the timely availability of the nutrients to the crop are the major yield-limiting factors. Thus, optimised nutrient management strategies are highly important for these alternative systems. The availability of inorganic and organic sources of nutrients has differences and this may affect different physiological processes of the rice crop at different growth stages. The comparison of grain yields alone among these diverse input systems does not provide the essential insights, which temporal physiological parameters provide. A detailed understanding of nutrient dynamics, physiological process, and their relationships to final crop yields can provide optimum nutrient management strategies in negating overwhelming conditions at early transition. We hypothesize that the dynamics of nutrients in critical stages of the rice crop has a significant impact despite the amounts and sources of nutrient on crop yield in different among input systems. This study mainly focused on identifying how the rice crop temporarily responses to different alternative fertilizer management systems, during the early transition of a conventional system to an organic. The main objective of this experiment was to understand the nutrient availability of an alternative nutrient management system and further was to assess the relationship of physiological variation of rice crop with the temporal changes of nutrient statuses. Hence, during this study, three fertilizer management systems were compared using yield and physiological parameters of direct-seeded rice under the dry zone condition.

\section{METHODOLOGY}

An experiment was conducted in the farm premises of the Faculty of Agriculture, Rajarata University of Sri Lanka from 2019 Yala season [dry season (DS)] to 2019/2020 Maha season [wet season (WS)] as a part of a long-term research project started from 2018/2019 Maha season. The site was located at Puliyankulama in the Anuradhapura district belongs to the agro-ecological region of DL1b. The study area consists of imperfectly drained ReddishBrown Earth soils (Dassanayake et al., 2020). The rainfall received in DS and WS of this study were $337.3 \mathrm{~mm}$ and $849.7 \mathrm{~mm}$, respectively. The mean seasonal temperatures were $30^{\circ} \mathrm{C}$ and $28^{\circ} \mathrm{C}$ for DS and WS, respectively, with an average maximum 
Table 1: Treatments and their respective nutrient contents.

\begin{tabular}{llll}
\hline $\begin{array}{l}\text { Treatment } \\
\text { No. }\end{array}$ & $\begin{array}{l}\text { Input management } \\
\text { system }\end{array}$ & $\begin{array}{l}\text { Mineral nutrient } \\
\mathbf{( k g} / \mathbf{h a})\end{array}$ & $\begin{array}{l}\text { Nutrients from alternative } \\
\text { sources (kg/ha) }\end{array}$ \\
\hline $\mathrm{T}_{1}$ & Conventional & $\mathrm{N}-103.5(\mathrm{Urea} 46 \%)$ & $\mathrm{N}-0$ \\
& & $\mathrm{P}-3.9\left(\mathrm{P}_{2} \mathrm{O}_{5} 43.7 \%\right)$ & $\mathrm{P}-0$ \\
& & $\mathrm{~K}-30.0\left(\mathrm{~K}_{2} \mathrm{O} 60 \%\right)$ & $\mathrm{K}-0$ \\
$\mathrm{~T}_{2}$ & \multirow{2}{*}{ Integrated } & $\mathrm{N}-51.8(\mathrm{Urea} 46 \%)$ & $\mathrm{N}-25.9$ \\
& & $\mathrm{P}-1.9\left(\mathrm{P}_{2} \mathrm{O}_{5} 43.7 \%\right)$ & $\mathrm{P}-0.65$ \\
& & $\mathrm{~K}-15\left(\mathrm{~K}_{2} \mathrm{O} 60 \%\right)$ & $\mathrm{K}-52.5$ \\
$\mathrm{~T}_{3}$ & \multirow{2}{*}{ Organic } & $\mathrm{N}-0$ & $\mathrm{~N}-51.8$ \\
& & $\mathrm{P}-0$ & $\mathrm{P}-1.3$ \\
& & $\mathrm{~K}-0$ & $\mathrm{~K}-104.9$ \\
\hline
\end{tabular}

temperature of $34.3^{\circ} \mathrm{C}$ in DS and $32.3^{\circ} \mathrm{C}$ in WS. The input systems were defined based on the elemental $\mathrm{N}$ supply and the sources Table 1 . The phosphorus and potassium rates were not standardised. The amount of these two elements were depended on the quality of materials used to supply $\mathrm{N}$ to both integrated and organic systems.

The experiment consisted of three main input systems, which were, $\mathrm{T}_{1}$ : Conventional input system $-100 \% \mathrm{~N}$ applied as inorganic fertilizer application based on recommended by the Department of Agriculture (DOA) 2013, T2: Integrated input system - 50\% N supply with inorganic fertilizer and $25 \% \mathrm{~N}$ supply with organic fertilizer application, respectively as of the conventional system and organic systems, $\mathrm{T}_{3}$ : Organic Input System - No inorganic fertilizer was added and organic manure was applied to satisfy the $50 \% \mathrm{~N}$ amount of the conventional system. Organic fertilizers, which previously calculated nitrogen content, was applied in relevant rates to get the required nitrogen content, and thereby managed the soil fertility. The three treatments were established as a Randomized Complete Block Design with six replicates. The size of the plot was $90 \mathrm{~m}^{2}$.

Pre-germinated seeds of Bg 300 rice variety were broadcasted at a rate of $120 \mathrm{~kg} / \mathrm{ha}$ in both WS and DS. The application of inorganic fertilizer was based on the DOA recommendation in 2013. Organic fertilizer was applied with basal dressing and at the third top dressing of inorganic fertilizers. Irrigation was done as per recommendation of DOA, and it was synchronised with the irrigation schedule recommended for that season. In case of water shortage, additional water was pumped to maintain the inundation as per the requirement. Pest control was carried out according to the DOA guidelines for both conventional and integrated systems; however, no major pest or disease of economic impact was not reported. Weeds in conventional and integrated systems were controlled using synthetic chemicals, while manual weeding was practiced in the organic input system.

Light interception by the crop in the field was measured at the heading stage using Line Quantum Sensor (LI-COR LI-191R) (LI-COR, Bioscience Inc, US) when the field receiving uniform solar radiation (noncloudy days). Four locations in a plot were randomly selected for this. LI 250A Light meter (LI-COR, Bioscience Inc, US) value at the eye level of the operator was taken by levelling the instrument horizontal above the crop and recorded as the incoming radiation (PAR) value. Then the instrument was held beneath the crop canopy and transmitted radiation was recorded. The difference between incoming and transmitted radiation provided the intercepted radiation.

Photosynthetic rate, stomatal conductance to water vapor, leaf temperature and water use efficiency were measured using a portable photosynthetic meter (Li-Cor 6400XT portable infra-red gas analyser) (LI-COR Biosciences Inc, US) in panicle initiation and heading stages of the crop under saturated conditions (Temperature- 32 ${ }^{\circ} \mathrm{C}$, Carbon dioxide concentration- $400 \mathrm{uml}$, Lamp$1800 \mu \mathrm{mol} / \mathrm{m}^{2} / \mathrm{s}$ ).

Relative leaf chlorophyll content was measured as SPAD (Soil Plant Analysis Development) value using SPAD-502 Plus- leaf chlorophyll meter (Konica Minolta Sensing Inc, Japan) at panicle initiation and heading stages. Three leaves were selected in the top middle and bottom of the plant and the SPAD values in five different places in one leaf were measured and the average was taken as the leaf relative chlorophyll value.

Two healthy rice plants from a plot were selected at the heading stage of rice to measure electrolyte leakage (EL). First, fully expanded leaf from each plant was detached from the rice plant at the predawn stage of the day and the fresh weight of the 
Table 2: Average mean values of soil properties of initial soil condition at the beginning of the Yala season.

\begin{tabular}{lr}
\hline Soil Property & Mean \\
\hline $\mathrm{pH}(1: 2.5$ soil: water $)$ & $7.39(0.36)$ \\
$\mathrm{EC}(\mathrm{dS} / \mathrm{m})$ & $0.07(0.03)$ \\
Total $\mathrm{N} \%$ & $0.03(0.02)$ \\
Available P $(\mathrm{mg} / \mathrm{kg})$ & $3.31(2.47)$ \\
Exchangeable K $(\mathrm{mg} / \mathrm{kg})$ & $69.98(16.49)$ \\
Organic C $\%$ & $0.96(0.19)$ \\
\hline
\end{tabular}

The number in the parenthesis is the standard deviation of the mean

leaf was taken (W). Then, the leaf was cut into one $\mathrm{cm}$ length pieces. The leaf pieces were washed in deionized water, blot dried on tissue papers and placed in $20 \mathrm{~mL}$ of deionized water containing polypropylene tubes at room temperature for one hour with gentle shaking. Then, Electrical Conductivity (EC) of the bathing solution (EC1) was measured using a multiparameter with EC prob (Hach Company, US). The total EL was measured after freezing subsequent samples at -6 ${ }^{\circ} \mathrm{C}$ for 12 hours (EC2). Then EL was expressed as $($ EC1/EC2) $\times 100$. Membrane stability index (MSI) percentage was calculated by using the following equation (Singh et al., 2008).

$\mathrm{MSI}=[1-(\mathrm{EC} 1 / \mathrm{EC} 2)] \times 100$

Above ground plant parts were collected at the hard dough stage and sampling was done by randomly placing a $50 \mathrm{~cm} \times 50 \mathrm{~cm}$ quadrate at four locations in the plot covering both front and back of the plot. The harvest was threshed by hand and all plant parts were oven-dried at the $60{ }^{\circ} \mathrm{C}$ until constant weight to measure plant biomass and final grain yield. Tissue concentration of nitrogen at panicle initiation and heading stage was determined by Kjeldhal procedure (Bremner,1982).

Soil samples were collected in topsoil $(0-15 \mathrm{~cm})$ to analysed basic soil chemical properties. Soil pH was analysed using a multiparameter with $\mathrm{pH}$ prob (Hach Company, US) in 1:2.5 soil to water ratio (Rowell, 1994). The Electrical Conductivity (EC) of the soil was measured using a multiparameter with EC prob (Hach Company, US) (Black, 1965). Soil total nitrogen was analysed using Kjedhal procedure (Bremner and Mulvaney, 1982). Exchangeable Potassium was determined by Ammonium Acetate extraction method (Jackson, 1958). Soil available phosphorous was extracted by $0.5 \mathrm{M}$ Sodium bicarbonate solution. Colorimetric method was used to quantify phosphorous after
Molybdate blue colour development in the extraction using UV Visible Spectrophotometer (Model UVD-2960) (Watanabe and Oslen, 1965). Organic matter in the soil was measured using Walkey and Black method (Smith and Mullins, 1991). Table 2 presented the mean soil properties of initial soil condition at the beginning of the Yala season.

Data were statistically analysed using the SAS computer programme version 9.0. Analysis of variance (ANOVA) was carried out using the MIXED model to determine the significant differences of input systems and means were separated using the least significant difference (LSD) method at 5\% probability level. The correlation between plant physiological parameters and leaf nitrogen concentration $[\mathrm{N}]$, plant biomass and economic yield was assessed using Pearson correlation coefficients at $5 \%$ probability level.

\section{RESULTS AND DISCUSSION}

There was a significant $(p<0.05)$ difference in the input system by season interaction on the Leaf $[\mathrm{N}]$ at the panicle initiation stage. Leaf $[\mathrm{N}]$ at panicle initiation and heading stages were significantly $(p<0.05)$ different among input systems and seasons (Table 3). Leaf [N] of the WS was higher than that of in the DS. The conventional system had significantly higher leaf $[\mathrm{N}]$ than the organic system at both stages and in both DS and WS. Leaf [N] in the integrated system was similar to the conventional system at the WS while not in the DS at both growth stages. The integrated system had significantly $(p<0.05)$ higher leaf $[\mathrm{N}]$ than that in the organic system except for that at the heading stage in the DS. Leaf [N] limits the yield and affects physiological processes in the rice crop (Pillai and De, 1979; Zhang and Kokubun, 2004; Pramanik and Bera, 2013). In this study, the leaf [N] is found to vary among input systems and seasons. The readily available $\mathrm{N}$ by mineral inputs may give the crop an advantage in taking up more $\mathrm{N}$ in comparison to that from organic inputs.

Light is a key factor that affects net primary productivity (Dewar, 1996). Higher light interception indicates the utilization of a higher amount of light energy by the leaves. Light interception values were significantly $(p<0.05)$ different among input systems and between seasons. However, the input system by season interaction was not significant $(p \geq 0.05)$. Crop light interception in the DS was significantly higher $(p<0.05)$ compared to that in the WS (Table 3). Significantly $(p<0.05)$ higher light interception was 
identified in conventional and integrated input systems in the DS, while the lowest was observed in the organic input system in the WS. Light interception always depends on the incident light intensity of each season. Higher light intensity was recorded in the DS than that in the WS due to less cloud cover and less frequency in rain events. Variation in canopy light availability, leaf lightharvesting capacity, and photosynthetic potentials are generally a function of foliage structural, plant density and canopy architectural characteristics (Maddonni et al., 2001; Niinemets and Sack, 2006; Acreche et al., 2009). Based on the observation of this study, rice crop canopies in the organic input system had droopy and wider leaves compared to other input systems. Integrated and conventional input systems showed erect and narrower leaves with an advantage more available $\mathrm{N}$ at the beginning with synthetic fertilizer inputs (data not presented). Droopy and wide leaves restrict light interception to the bottom leaves causing low overall canopy light interception. Due to the lack of plant nitrogen, the leaf width increases by phenological plasticity for the better light penetration (Setter et al., 1995), which may also be the reason to produce more droopy leaves with wider leaf blades, despite low light interception by less greenness compared to the nitrogen-rich conventional system. However, in this study, there was no correlation between light interception and leaf [N] (Table 5). Correlation of the crop biomass and light interception resulted a significantly negative correlation for the conventional $(\mathrm{r}=-0.97$; $p=<0.001)$ and integrated $(\mathrm{r}=-0.85 ; p=0.03)$ input systems in the DS. However, a robust correlation in the aforementioned input systems was observed in the DS only. From the lower plant biomass, it showed less plant growth, which led to the lower spatial structure of the plant. It increases the penetration of light through the plant canopy. It may be the main reason for the negative relationship between light absorption and crop biomass.

Leaf temperature (Table 3 ) at the heading stage was significantly $(p<0.05)$ different in the input system by season interaction. But it was significantly $(p<0.05)$ different between DS and WS at both panicle initiation and heading stages. The higher leaf temperature was shown in the WS than that in both stages. Leaf temperature is strongly influenced by air temperature, wind speed, and air humidity (Martin et al. 1999). There were no significant $(p<0.05)$ differences in each input system in both seasons. The highest leaf temperature observed in the WS was due to the lower water-use efficiency (Pallas et al., 1967). Leaf temperature did not show a direct correlation with crop biomass production and final grain yield.
While leaf $[\mathrm{N}]$ was significantly different in each system, leaf temperature in integrated $(\mathrm{r}=-0.82$; $p=0.05)$ and organic ( $\mathrm{r}=-0.88 ; p=0.02)$ input systems in the DS reported a negative correlation with the leaf $[\mathrm{N}]$. However, in the WS increasing leaf temperature was affected to reduce the leaf $[\mathrm{N}]$ in the conventional $(\mathrm{r}=-0.90 ; p=0.01)$ and organic $(\mathrm{r}=-0.90 ; p=0.01)$ input systems (Table 5). With different seasons response of leaf temperature on leaf [N] varied with different input systems.

Relative leaf chlorophyll content (SPAD) was (Table 3) significantly $(p<0.05)$ different in the input system by season interaction. And it was varied SPAD values among input systems and seasons both panicle initiation and heading stages. The WS resulted significantly $(p<0.05)$ high SPAD values compared to DS. Significantly $(p<0.05)$ highest SPAD values were observed in the conventional input system at both stages in the DS but not in the WS. In the WS, the SPAD values in the integrated input system were similar to that of the level conventional input system in both growth stages. There was no significant ( $p>0.05)$ difference in SPAD between integrated and organic input systems in the WS at heading stage. Rice plants are susceptible to unfavourable environmental conditions, such as high temperatures, during specific developmental periods (Fageria, 2001; Jagadish et al., 2007), while the plasticity of chlorophyll content is possible with low availability of light with greater accumulation of chlorophylls. The impact of $\mathrm{N}$ fertilizer is well established for increasing chlorophyll content (Varvel et al., 1997; Pramanik and Bera, 2013), thus it can be the main reason for high chlorophyll values recorded in both conventional and integrated input systems compared to the organic input system. The WS resulted in a high leaf [N] compared to the DS (Table 3), and ultimately resulted in an increase in leaf chlorophyll content. At the panicle initiation stage during WS, the integrated input system showed similar high leaf $[\mathrm{N}]$ as the conventional input system and it resulted higher chlorophyll content in the integrated input system parallel to the conventional input system. Crop biomass in the organic input system at the DS was significantly correlated with relative leaf chlorophyll content $(\mathrm{r}=0.82 ; p=0.05)$. Leaf $[\mathrm{N}]$ and chlorophyll content were also positively correlated $(p=0.05, r=0.82)$ (Table 5). The photosynthetic rate at the panicle initiation stage was significantly $(p<0.05)$ different at different seasons and input systems. Even though, photosynthetic rate showed a significant $(p<0.05)$ difference among input systems at the heading stage, it was similar between the seasons. At the panicle initiation stage, the conventional input system had the highest photosynthetic rate in both 
Table 3: Effects of input systems, seasonal variation and their interaction on leaf total nitrogen, light interception, leaf temperature and relative leaf chlorophyll content in panicle initiation stage and heading stage of rice crop.

\begin{tabular}{|c|c|c|c|c|c|c|c|c|c|c|c|c|c|c|}
\hline & \multicolumn{4}{|c|}{ Leaf Nitrogen Concentration (mg/g) } & \multirow{2}{*}{\multicolumn{2}{|c|}{$\begin{array}{c}\begin{array}{c}\text { Light Interception } \\
\left(\mu \mathrm{mol} / \mathrm{m}^{2} / \mathrm{S}\right)\end{array} \\
\text { Heading }\end{array}$}} & \multicolumn{4}{|c|}{$\begin{array}{l}\text { Leaf Temperature } \\
\left({ }^{\circ} \mathrm{C}\right)\end{array}$} & \multicolumn{4}{|c|}{$\begin{array}{l}\text { Relative Leaf Chlorophyll Content } \\
\text { (SPAD) }\end{array}$} \\
\hline & \multicolumn{2}{|c|}{ Panicle Initiation } & \multicolumn{2}{|c|}{ Heading } & & & \multicolumn{2}{|c|}{ Panicle Initiation } & \multicolumn{2}{|c|}{ Heading } & \multicolumn{2}{|c|}{ Panicle Initiation } & \multicolumn{2}{|c|}{ Heading } \\
\hline & DS & WS & DS & WS & DS & WS & DS & WS & DS & WS & DS & WS & DS & WS \\
\hline Conventional & $25.3 \mathrm{ab}$ & $26.0 \mathrm{a}$ & $14.4 \mathrm{~b}$ & $19.7 \mathrm{a}$ & $93.02 \mathrm{a}$ & $61.23 \mathrm{bc}$ & $29.93 b$ & $30.96 \mathrm{a}$ & $29.59 d$ & $33.09 a$ & $36.29 a$ & $36.27 a$ & $37.08 \mathrm{a}$ & $36.30 \mathrm{ab}$ \\
\hline Integrated & $20.5 c$ & $25.6 \mathrm{a}$ & $11.6 \mathrm{c}$ & $18.4 \mathrm{a}$ & $97.13 a$ & $52.61 \mathrm{~cd}$ & $29.60 b$ & $31.14 \mathrm{a}$ & $30.45 c$ & $32.26 \mathrm{~b}$ & $31.21 \mathrm{~b}$ & $35.62 \mathrm{a}$ & $33.68 \mathrm{bc}$ & $34.62 \mathrm{abc}$ \\
\hline Organic & $13.8 \mathrm{~d}$ & $21.8 \mathrm{bc}$ & $09.5 \mathrm{c}$ & $14.7 \mathrm{~b}$ & $68.05 b$ & $47.42 \mathrm{~d}$ & $29.53 b$ & $31.35 a$ & $30.21 \mathrm{~cd}$ & $32.25 b$ & $25.84 \mathrm{c}$ & $29.68 b$ & $27.82 \mathrm{~d}$ & $32.53 c$ \\
\hline $\mathrm{CV} \%$ & 7.2 & 4.1 & 8.1 & 4.3 & 7.1 & 8.04 & 1.16 & 0.97 & 0.87 & 0.61 & 3.22 & 2.09 & 3.44 & 2.36 \\
\hline \multicolumn{15}{|l|}{ P-values } \\
\hline IS & $<.0001$ & & $<.0001$ & & 0.001 & & 0.91 & & 0.8179 & & $<.001$ & & $<.001$ & \\
\hline S & $<.0001$ & & $<.0001$ & & $<.0001$ & & $<.001$ & & $<.001$ & & $<.001$ & & 0.043 & \\
\hline IS $x \mathrm{~S}$ & 0.0176 & & 0.4296 & & 0.0888 & & 0.15 & & $<.001$ & & 0.028 & & 0.019 & \\
\hline
\end{tabular}

Means values followed by the same letter in each growth stage are not significantly different at $p<0.05$ (LSD)

IS is input system; $\mathrm{S}$ is season. 
Table 4: Effects of input systems, seasonal variation and their interaction on photosynthesis rate, stomatal conductance to water vapour, water use efficiency, membrane stability in panicle initiation stage and heading stage of rice crop.

\begin{tabular}{|c|c|c|c|c|c|c|c|c|c|c|c|c|c|c|}
\hline & \multicolumn{4}{|c|}{$\begin{array}{l}\text { Photosynthetic Rate ( } \mu \mathrm{mol} \\
\left.\qquad \mathrm{CO}_{2} / \mathrm{cm}^{2} / \mathrm{S}\right)\end{array}$} & \multicolumn{4}{|c|}{$\begin{array}{l}\text { Stomatal Conductance to Water } \\
\text { Vapor }\left(\mathrm{mol} \mathrm{H}_{2} \mathrm{O} / \mathrm{m}^{2} / \mathrm{S}\right)\end{array}$} & \multicolumn{4}{|c|}{ Water Use Efficiency (\%) } & \multirow{2}{*}{\multicolumn{2}{|c|}{$\begin{array}{c}\begin{array}{c}\text { Membrane } \\
\text { Stability (\%) }\end{array} \\
\text { Heading }\end{array}$}} \\
\hline & \multicolumn{2}{|c|}{ Panicle Initiation } & \multicolumn{2}{|c|}{ Heading } & \multicolumn{2}{|c|}{ Panicle Initiation } & \multicolumn{2}{|c|}{ Heading } & \multicolumn{2}{|c|}{ Panicle Initiation } & \multicolumn{2}{|c|}{ Heading } & & \\
\hline & DS & WS & DS & WS & DS & WS & DS & WS & DS & WS & DS & WS & DS & WS \\
\hline Conventional & $19.37 \mathrm{ab}$ & $20.54 a$ & $13.39 \mathrm{a}$ & $13.85 a$ & $0.76 \mathrm{ab}$ & $0.44 \mathrm{~b}$ & $1.00 \mathrm{ab}$ & $0.92 \mathrm{ab}$ & $1.50 \mathrm{a}$ & $1.15 \mathrm{a}$ & $0.66 \mathrm{a}$ & $0.42 b$ & $76.89 \mathrm{~b}$ & $95.37 a$ \\
\hline Integrated & $14.49 \mathrm{bc}$ & $19.12 \mathrm{ab}$ & $13.59 a$ & $11.83 a$ & $0.83 \mathrm{ab}$ & $1.88 \mathrm{a}$ & $1.32 \mathrm{a}$ & $1.19 \mathrm{a}$ & $1.28 \mathrm{a}$ & $1.23 a$ & $0.52 \mathrm{ab}$ & $0.52 \mathrm{ab}$ & $72.53 b$ & $95.77 a$ \\
\hline Organic & $8.96 c$ & $15.26 \mathrm{~b}$ & $7.28 b$ & 11.69ab & $0.66 \mathrm{ab}$ & 1.13ab & $0.54 \mathrm{~b}$ & $1.09 \mathrm{ab}$ & $1.17 \mathrm{a}$ & $1.25 \mathrm{a}$ & $0.43 \mathrm{~b}$ & $0.41 \mathrm{~b}$ & $40.44 \mathrm{c}$ & $95.41 \mathrm{a}$ \\
\hline CV \% & 22.79 & 16.05 & 16.44 & 10.89 & 17.4 & 23.92 & 25.77 & 16.33 & 26.95 & 22.27 & 15.43 & 14.54 & 5.46 & 3.02 \\
\hline \multicolumn{15}{|l|}{ P-values } \\
\hline IS & \multicolumn{2}{|c|}{$<.001$} & \multicolumn{2}{|c|}{0.03} & \multicolumn{2}{|c|}{0.27} & \multicolumn{2}{|c|}{0.11} & \multicolumn{2}{|c|}{0.92} & \multicolumn{2}{|c|}{0.11} & \multicolumn{2}{|c|}{$<.0001$} \\
\hline$S$ & \multicolumn{2}{|c|}{0.006} & \multicolumn{2}{|c|}{0.42} & \multicolumn{2}{|c|}{0.29} & \multicolumn{2}{|c|}{0.51} & \multicolumn{2}{|c|}{0.64} & \multicolumn{2}{|c|}{0.09} & \multicolumn{2}{|c|}{$<.0001$} \\
\hline IS $x \mathrm{~S}$ & \multicolumn{2}{|c|}{0.32} & \multicolumn{2}{|c|}{0.15} & \multicolumn{2}{|c|}{0.34} & \multicolumn{2}{|c|}{0.22} & \multicolumn{2}{|c|}{0.74} & \multicolumn{2}{|c|}{0.1} & \multicolumn{2}{|c|}{$<.0001$} \\
\hline
\end{tabular}

Means values followed by same letters in each growth stage are not significantly different at $p<0.05$ (LSD)

IS is input system; $\mathrm{S}$ is season. 
DS and WS. The photosynthetic rate in the integrated input system was not significantly $(p>0.05)$ different from the conventional input system in both stages. The lowest value in panicle initiation was observed at organic and integrated input systems. The photosynthetic rate was lower at the heading stage compared to the panicle initiation stage. Conventional and integrated input systems showed significantly $(p<0.05)$ highest values at the heading stage, while organic showed the lowest in the DS. Photosynthetic rates were similar $(p>0.05)$ among all input systems in the heading stage of the WS (Table 5).

With different input applications, leaf [N] also varied. According to the results of Mitsui and Ishii, (1938); Yoshida and Coronel, (1976); Uchida et al., (1982); Makino et al., (1988), leaf photosynthetic rate and leaf $[\mathrm{N}]$ were closely related in rice, hence maintaining adequate leaf $\mathrm{N}$ throughout the growing period is crucial for achieving high yield (Yoshida, 1981). However, in this study, the photosynthetic rate and leaf $[\mathrm{N}]$ were only correlated in the integrated input system in the WS $(\mathrm{r}=0.85 ; p=0.03)$ (Table 5). As well as photosynthetic rate in the integrated system at the panicle initiation in WS showed a higher value equal to the conventional that resulted in an increase in leaf [N] with time. This showed that the continuous application of organic manure with a half dose of synthetic fertilizer caused to improve the leaf $[\mathrm{N}]$ than the previous season (Table 3 ).

There was no significant ( $p>0.05)$ effect of input systems, seasons and their interaction on stomatal conductance and water use efficiency at both growth stages (Table 4). Input systems and seasonal changes did not affect the stomatal conductance to water vapour and water use efficiency, while stomatal conductance was not significantly different from input systems. Stomatal conductance in the integrated input system showed a significantly positive correlation with the leaf nitrogen content $(\mathrm{r}=0.85 ; p=0.03)$ (Table 5).

Membrane stability was measured only at the heading stage. There was a significant $(p<0.05)$ input system by season interaction, on membrane stability. The WS showed higher values than those of the DS. In the DS, conventional and integrated input systems showed similar and higher membrane stability while organic had the lowest membrane stability. No significant $(p>0.05)$ differences were observed among treatments in the WS (Table 4). Good water management and low water stress in the WS resulted in increasing membrane stability in all input systems (Khadem et al., 2010). However, during the DS, low water availability and high-temperature stress can lead to a difference in membrane stability. Due to good nutrient management in the conventional and integrated systems, they showed considerably high membrane stability compared to organic. The DS resulted in low membrane stability due to high water stress and temperature stress (Agarie et al., 1995). High temperatures affect membrane stability through lipid peroxidation, leading to the production of peroxide ions and malondialdehyde (MDA) (Wahid et al., 2007). Therefore, changes in the concentration of MDA may also be a cause for low membrane stability in the organic input system. In the DS, significantly positive correlation $(\mathrm{r}=1.00 \mathrm{p}=0.04)$ between membrane stability and yield was identified in the integrated input system. Crop biomass in the integrated input system in WS showed a positive correlation with membrane stability $(\mathrm{r}=1.00 ; p=0.03)$. Leaf $[\mathrm{N}]$ in conventional $(\mathrm{r}=1.00 ; p=<0.001)$ and organic $(\mathrm{r}=-1.00 ; p=0.02)$ input systems in the DS correlated with the membrane stability (Table 5).

There were significant differences among input systems and seasons on grain yield while crop biomass significantly $\operatorname{varied}(p<0.05)$ only with input systems. However, the harvest index (HI) was significantly $(p<0.05)$ affected by the season only. Crop biomass of conventional and integrated input systems reported significantly $(p<0.05)$ higher values than organic in both seasons. Accordingly, the grain yields of conventional and integrated input systems were significantly $(p<0.05)$ higher than the organic input system. The mean yields were low in the DS. The crop biomass and grain yield of the WS were significantly $(p<0.05)$ higher compared to the DS concerning each input system (Table 6).

Generally, the higher yield was recorded in the DS than WS due to high solar irradiance in the DS (Laza et al., 2003). However, in this study, grain yield in the WS was greater than the DS. It might be resulted due to a higher temperature in the DS than the WS, which causes an increase in pollen sterility and percent empty spikelets. According to Kim et al. (1996) yield decreases in higher temperature treatment at 29.3 to $31.1^{\circ} \mathrm{C}$ when compared to 26.0 to $27.2^{\circ} \mathrm{C}$. The mean seasonal temperature was in the supra-optimal range during the DS of this study. Significantly higher HI was reported in the WS than the DS also reasons for the higher grain yield in the WS than the DS. Proper water and N management in the WS increase the crop growth and enhance the remobilization of assimilates from vegetative parts to grains during grain filling and it leads to increase HI (Ju et al., 2009). 
Table 5: Correlation for physiological parameters with crop biomass, grain yield and leaf [N] in both DS and WS.

\begin{tabular}{|c|c|c|c|c|c|c|c|c|c|c|c|c|c|c|c|c|c|c|}
\hline & \multicolumn{9}{|c|}{ DS } & \multicolumn{9}{|c|}{ WS } \\
\hline & \multicolumn{3}{|c|}{ Crop Biomass } & \multicolumn{3}{|c|}{ Grain Yield } & \multicolumn{3}{|c|}{ Leaf [N] } & \multicolumn{3}{|c|}{ Crop Biomass } & \multicolumn{3}{|c|}{ Grain Yield } & \multicolumn{3}{|c|}{ Leaf [N] } \\
\hline & $\mathbf{T}_{1}$ & $\mathbf{T}_{2}$ & $\mathbf{T}_{3}$ & $\mathbf{T}_{1}$ & $\mathbf{T}_{2}$ & $\mathbf{T}_{3}$ & $\mathbf{T}_{1}$ & $\mathbf{T}_{2}$ & $\mathbf{T}_{3}$ & $\mathbf{T}_{1}$ & $\mathbf{T}_{2}$ & $\mathbf{T}_{3}$ & $\mathbf{T}_{1}$ & $\mathbf{T}_{2}$ & $\mathbf{T}_{3}$ & $\mathbf{T}_{1}$ & $\mathbf{T}_{2}$ & $\mathbf{T}_{3}$ \\
\hline Light & $-0.97^{*}$ & -0.85 & 0.24 & 0.33 & -0.79 & 0.48 & -0.05 & -0.08 & -0.21 & 0.06 & 0.15 & 0.09 & -0.75 & 0.47 & 0.07 & -0.30 & -0.33 & 0.19 \\
\hline Interception & 0.00 & 0.03 & 0.64 & 0.52 & 0.06 & 0.34 & 0.93 & 0.88 & 0.69 & 0.92 & 0.78 & 0.87 & 0.09 & 0.35 & 0.90 & 0.56 & 0.52 & 0.72 \\
\hline Leaf & 0.49 & 0.01 & -0.22 & -0.75 & 0.03 & -0.11 & 0.24 & -0.82 & -0.88 & -0.20 & -0.07 & -0.23 & -0.34 & 0.11 & -0.24 & -0.90 & -0.68 & -0.90 \\
\hline Temperature & 0.33 & 0.99 & 0.67 & 0.09 & 0.95 & 0.84 & 0.65 & 0.05 & 0.02 & 0.70 & 0.90 & 0.66 & 0.51 & 0.83 & 0.65 & 0.01 & 0.14 & 0.01 \\
\hline Relative Leaf & 0.26 & 0.51 & 0.82 & -0.74 & 0.49 & 0.76 & -0.47 & -0.42 & -0.54 & -0.39 & 0.23 & -0.34 & 0.15 & 0.02 & -0.34 & 0.20 & 0.95 & -0.63 \\
\hline $\begin{array}{l}\text { Chlorophyll } \\
\text { Content }\end{array}$ & 0.61 & 0.30 & 0.05 & 0.09 & 0.32 & 0.08 & 0.34 & 0.40 & 0.27 & 0.45 & 0.67 & 0.51 & 0.77 & 0.96 & 0.51 & 0.70 & 0.00 & 0.18 \\
\hline Photosynthesis & -0.19 & -0.53 & -0.34 & -0.04 & -0.56 & -0.19 & 0.47 & 0.23 & 0.25 & 0.52 & -0.18 & -0.17 & 0.40 & -0.31 & -0.18 & 0.53 & 0.85 & 0.37 \\
\hline Rate & 0.72 & 0.28 & 0.51 & 0.94 & 0.25 & 0.71 & 0.34 & 0.67 & 0.63 & 0.29 & 0.73 & 0.74 & 0.44 & 0.55 & 0.74 & 0.27 & 0.03 & 0.48 \\
\hline Stomatal & 0.01 & 0.23 & 0.17 & -0.23 & 0.30 & 0.26 & -0.36 & -0.52 & 0.18 & -0.45 & -0.01 & 0.480 .33 & 0.19 & -0.11 & 0.49 & -0.26 & 0.92 & -0.35 \\
\hline $\begin{array}{l}\text { Conductance } \\
\text { to Water } \\
\text { Vapor }\end{array}$ & 0.99 & 0.67 & 0.74 & 0.67 & 0.57 & 0.62 & 0.48 & 0.29 & 0.74 & 0.37 & 0.98 & & 0.72 & 0.83 & 0.32 & 0.62 & 0.01 & 0.50 \\
\hline Water Use & -0.55 & -0.33 & -0.54 & 0.30 & -0.38 & -0.44 & 0.46 & 0.63 & 0.34 & 0.18 & 0.03 & -0.26 & 0.10 & -0.06 & -0.26 & 0.89 & 0.99 & 0.78 \\
\hline Efficiency & 0.26 & 0.53 & 0.27 & 0.56 & 0.46 & 0.38 & 0.36 & 0.18 & 0.51 & 0.74 & 0.96 & 0.62 & 0.85 & 0.91 & 0.62 & 0.02 & 0.00 & 0.07 \\
\hline Membrane & 0.75 & 0.98 & 0.79 & 0.13 & 1.00 & 0.92 & 1.00 & 0.85 & -1.00 & 0.52 & 1.00 & -0.02 & 0.99 & 0.93 & -0.05 & 0.27 & 0.83 & 0.79 \\
\hline Stability & 0.46 & 0.11 & 0.42 & 0.92 & 0.04 & 0.26 & 0.00 & 0.36 & 0.02 & 0.65 & 0.03 & 0.98 & 0.08 & 0.24 & 0.97 & 0.83 & 0.38 & 0.42 \\
\hline
\end{tabular}

The value before the * mark is the Pearson correlation coefficient and the italic value is the probability value 
Table 6: Effects of seasonal variation and input systems on the crop biomass and grain yield of rice crop.

\begin{tabular}{lcccccc}
\hline & \multicolumn{2}{c}{ Crop biomass (t/ha) } & \multicolumn{2}{c}{ Grain yield (t/ha) } & \multicolumn{2}{c}{ Harvest index (\%) } \\
\cline { 2 - 8 } & DS & WS & DS & WS & DS & WS \\
\cline { 2 - 8 } Conventional & $9.9 \mathrm{ab}$ & $11.8 \mathrm{a}$ & $5.1 \mathrm{~b}$ & $7.0 \mathrm{a}$ & $52.4 \mathrm{ab}$ & $58.8 \mathrm{a}$ \\
Integrated & $11.1 \mathrm{a}$ & $10.7 \mathrm{a}$ & $5.0 \mathrm{~b}$ & $6.0 \mathrm{ab}$ & $44.6 \mathrm{~b}$ & $56.1 \mathrm{a}$ \\
Organic & $6.4 \mathrm{c}$ & $8.4 \mathrm{bc}$ & $2.9 \mathrm{c}$ & $5.1 \mathrm{~b}$ & $44.9 \mathrm{~b}$ & $59.5 \mathrm{a}$ \\
CV\% & 9.4 & 6.4 & 8.8 & 7.1 & 7.9 & 4.5 \\
P-values & & & & & & 0.22 \\
Input system (IS) & $<.0001$ & & 0.0011 & \multicolumn{2}{c}{$<.0001$} \\
Season (S) & 0.0788 & & 0.0005 & 0.3958 \\
IS*S & 0.2264 & & 0.5247 & & & \\
\hline
\end{tabular}

Means values followed by the same letter in each season are not significantly different at $p<0.05$ (LSD)

With fewer restrictions in water availability and the temperature very much close to the optimal range for many physiological functions, with adequate nitrogen supply in the WS, it could be the most appropriate season for organically grown rice. Furthermore, a rotation with an upland cereal or a pulse in the DS could be ideal for maintaining the productivity of such a system. Correlation analysis for plant biomass and economical yield in both season ( $\mathrm{r}=0.97 ; p=<0.0001$ [DS], $\mathrm{r}=0.96$; $p=<0.0001$ [WS]) resulted positive correlation with plant biomass and yield. A similar observation was also reported by Akita, (1989) and Amano et al., (1993). Crop biomass production in different input systems equally collaborated to the partitioning of assimilating to the grain production. According to Yang et al. (2008), above ground total biomass at physiological maturity was a crucial physiological factor to the yield gap between DS and WS. However, in this study, HI was not correlated with grain yield and crop biomass

\section{CONCLUSION}

The conventional, integrated, and organic nutrient management systems were different in some measured physiological attributes measured during panicle initiation and heading stages, while for certain parameters were influenced by the season. The organic system showed low canopy light interception, photosynthetic rate, and leaf chlorophyll content compared to the conventional system. The integrated system showed intermediate physiological activity but light interception, relative leaf chlorophyll content and photosynthetic rate were similar compared to conventional in the wet season. Even though there were differences in leaf [N] among input systems, no correlation was identified with the measured physiological processes among input systems revealing that other nutrients could also be the limiting factors. However, crop yields followed the differences observed among inputs in their physiological processes and leaf $\mathrm{N}$ content, giving the highest yield in the conventional system compared to the organic system. Yield reduction was greater in the organic system in the DS (43\%) compared to the WS (27\%).

\section{ACKNOWLEDGMENT}

The research was funded by Presidential Secretariat which is greatly appreciated.

Mediterranean wheat. Field Crop Research, 110, 91- 97.

Agarie, S., Hanaoka, N., Kubota, F., Agata, W. and Kaufman, P.B. (1995). Measurement of cell
Acreche, M.M., Briceno-Felix, G., Sanchez, J.A.M. and Slafer, G.A. (2009). Radiation interception and use efficiency as affected by breeding in 
membrane stability evaluated by electrolyte leakage as a drought and heat tolerance test in rice (Oryza sativa L.). Journal of the Faculty of Agriculture, Kyushu University, 40(1), 233-240.

Akita, S. (1989). Improving yield potential in tropical rice. In Progress in irrigated rice research. IRRI, Los Baños, the Philippines. 4173.

Amano, T., Zhu, Q., Wang, T., Inoue, N. and Tanaka. H. (1993). Case studies on high yields of paddy rice in Jiangsu Province China: I. Characteristics of grain production. Japanese Journal of Crop Science26. 62, 267-274.

Bhakiyathu, B.S., Krihnakumar, S. and Natarajan, S.K. (2005). Response to rice crop to organic manuring in high $\mathrm{pH}$ soil. Asian Journal of Plant Sciences, 4, 5, 524-526.

Black, C.A. (1965). Methods of soil analysis (Agronomy No.9). American Society of Agronomy.Inc, Publisher, Madison, Wisconsin USA.

Bremner, J.M. and Mulvaney, C.S. (1982). "Total nitrogen" In: Methods of Soil Analysis. American Society of Agronomy, Soil Science Society of America, Madison, Wisconsin. 9, 595624.

Chen, J.H. (2006). The combined use of chemical and organic fertilizers and/or bio-fertilizer for crop growth and soil fertility. In International workshop on sustained management of the soilrhizosphere system for efficient crop production and fertilizer use. 16, 20.

Dabbert, S. and Madden, P., (1986). The transition to organic agriculture: A multi-year simulation model of a Pennsylvania farm. American Journal of Alternative Agriculture, 1(3), 99-107.

Dassanayake, A.R., De Silva, G.G.R. and Mapa, R.B., (2020). Major Soils of the Dry Zone and Their Classification. In: The Soils of Sri Lanka, Springer, Cham. 49-67.

Dewar, R.C. (1996). The correlation between plant growth and intercepted radiation: An interpretation in terms of optimal plant nitrogen content. Annals of Botany, 78, 125136.

Dissanayake, D.M.D., Premaratne, K.P. and Sangakkara, U.R. (2014). Integrated Nutrient Management for Lowland Rice (Oryza sativa L.) in the Anuradhapura District of Sri Lanka.
Tropical Agricultural Research, 25(2), 266 271.

Ekanayake, H.K.J. (2009). The impact of fertilizer subsidy on paddy cultivation in Sri Lanka. Staff Studies, 36(1), 73-101.

Evenson, R.E. and Gollin, D. (2003). Assessing the Impact of the Green Revolution,1960 to 2000. Science, 300(5620), 758-762.

Fageria, N.K. and Filho, M.P.B. (2001). Nitrogen use efficiency in lowland rice genotypes. Communications in Soil Science and Plant Analysis, 32, 2079-2089.

Hazell, P.B. (2009). The Asian green revolution (IFPRI Discussion Paper 00911). Washington DC: International Food Policy Research Institute.

Jackson, M.L. (1958). Soil chemical analysis. Prentice-Hall Inc., Englewood Clliffs, N.J, 87110.

Jagadish, S.V.K., Craufurd, P.Q. and Wheeler, T.R., (2007). High temperature stress and spikelet fertility in rice (Oryza sativa L.). Journal of Experimental Botany, 58(7), 1627-1635.

Ju, J., Yamamoto, Y., Wang, Y.L., Shan, Y.H., Dong, G.C., Miyazaki, A. and Yoshida T. (2009). Genotypic differences in dry matter accumulation, nitrogen use efficiency and harvest index in recombinant inbred lines of rice under hydroponic culture. Plant Production Science, 12, 208-216.

Khadem, S.A., Galavi, M., Ramrodi, M., Mousavi, S.R., Rousta, M.J. and Rezvani-Moghadam, P., (2010). Effect of animal manure and superabsorbent polymer on corn leaf relative water content, cell membrane stability and leaf chlorophyll content under dry condition. Australian Journal of Crop Science, 4(8), 642.

Kim, H.Y., Horie, T., Nakagawa, H. and Wada, K. (1996). Effects of elevated CO2 concentration and high temperature on growth and yield of rice: II. The effect on yield and its components of Akihikari rice. Japanese Journal of Crop Science, 65, 644-651.

Kumar, R. and Prakash, O. (2019). The impact of chemical fertilizers on our environment and ecosystem. In: Research Trends in Environmental Sciences, 69-86. 
Laza, R.C., Peng, S., Akita, S. and Saka, H. (2003). Contribution of biomass partitioning and translocation of grain yield under sub-optimum growing conditions in irrigated rice. Plant Production Science, 6, 28-35.

Maddonni, G.A., Otegui, M.E. and Cirilo, A.G. (2001). Plant population density, row spacing and hybrid effects on maize canopy architecture and light attenuation. Field Crop Research, 71, 183193.

Martin, T.A., Hinckley, T.M., Meinzer F.C. and Sprugel D.G. (1999). Boundary layer conductance, leaf temperature and transpiration of Abies amabilis branches. Tree Physiology, 19, 435-443.

Mitsui, S. and Y. Ishii. (1938). Effects of supply of three major nutrients on photosynthetic rate of rice seedlings. Journal of the Science of Soil and Manure (Japan), 12, 287-289.

Niinemets, Ü. and Sack, L. (2006). Structural determinants of leaf light-harvesting capacity and photosynthetic potentials. In Progress in botany. Springer, Berlin, Heidelberg. 385-419.

Pallas, J.E., Michel, B.E. and Harris, D.G. (1967). Photosynthesis, transpiration, leaf temperature, and stomatal activity of cotton plants under varying water potentials. Plant Physiology, 42(1), 76-88.

Pillai, K.G. and R. De. (1979). Mineral nitrogen status of soil, leaf nitrogen content and grain yield of rice variety 'Jaya' as affected by water and nitrogen fertilizer management. Field Crops Research, 2, 125-133.

Pramanik, K. and Bera, A.K., (2013). Effect of seedling age and nitrogen fertilizer on growth, chlorophyll content, yield and economics of hybrid rice (Oryza sativa L.). International Journal of Agronomy and Plant Production, 4(5), 3489-3499.

Rahman, S. (2015). Green revolution in India: environmental degradation and impact on livestock. Asian Journal of Water, Environment and Pollution, 12(1), 75-80.

Rao, G.S., Baradhan, G., Sureshkumar, S.M., Immanuel, R.R. and Ramesh, S. (2019). Influence of integrated nutrient management practices on growth and yield of rice-green gram cropping system, Plant Archives, 19(1), 441-443.
Reganold, J.P. and Wachter, J.M. (2016). Organic agriculture in the twenty-first century. Nature Plants, 2, 15221.

Rowell, D.L. (1994). Soil science: Methods \&amp; applications. Longman Scientific \&amp; Technical, Longman Group UK Ltd, 169.

Seneviratne, G. (2009). Collapse of beneficial microbial communities and deterioration of soil health: a cause for reduced crop productivity Current Science, 96, 633.

Setter, T.L., Conocono, E.A., Egdane, J.A. and Kropff, M.J. (1995). Possibility of Increasing Yield Potential of Rice by Reducing Panicle Height in the Canopy. I. Effects of Panicles on Light Interception and Canopy Photosynthesis. Functional Plant Biology, 22(3), 441-451.

Smith, K. A. and MULLINS, C. E. (1991). Soil and environmental analysis physical methods. Marcel Dekker New York.

Singh, A., Kumar, J. and Kumar, P. (2008). Effects of plant growth regulators and sucrose on postharvest physiology, membrane stability and vase life of cut spikes of gladiolus. Plant Growth Regulation, 55(3), 221.

Sirisena, D.N., Wanninayake, W.M.N. and Silva, A.G.S.D. (2016). Long term application of organic manure and chemical fertilizers on rice productivity and fertility in paddy growing soils in Kurunegala district. Tropical Agriculturist, 164.

Uchida, N., Y. Wada, and Murata, Y. (1982). Studies on the changes in the photosynthetic activity of a crop leaf during its development and senescence. II. Effect of nitrogen deficiency on the changes in the senescing leaf of rice. Japanese Journal of Crop Science, 51, 577-583.

Varvel, G.E., Schepers, J.S. and Francis, D. (1997). Ability for in season correction of nitrogen deficiency in corn using chlorophyll meters. Soil Science Society of America Journal, 61, 12331239.

Wahid, A., Gelani, S., Ashraf, M. and Foolad, M. (2007). Heat tolerance in plants: an overview. Environmental and Experimental Botany, 61, 199-223.

Watanabe, F.S. and Oslen, S.R. (1965). Test of an Ascorbic Acid Method for Determining Phosphorus in Water and NaHCO3 Extracts 
from the Soil. Soil Science Society of America Journal, 29, 677-678.

Wickramasinghe, W.M.A.D.B. (2005). Management of Intermediate Zones soils for rice. In: Soils of the Intermediate Zones of Sri Lanka Eds. R.B. Mapa, A.R. Diianayake and H.B. Nayakakorale. Soil Science Society of Sri Lanka, Special publication N0.4 Sarvodaya, Vishva Lekha, 191196.

Wijebandara, D.M.D.I., Dasog, G.S., Patil, P.L. and Hebbar, M. (2008). Effect of nutrient levels and biofertilizer on growth and yield of paddy under system of rice intensification (SRI) and conventional methods of cultivation. Tropical Agricultural Research, 20, 343-353.

Wimalawansa, S. (2014). Escalating chronic kidney diseases of multi-factorial origin in Sri Lanka causes, solutions, and recommendations. Environmental Health and Preventive Medicine, 19(6), 375-394.

Yadav, R.L., Dwivedi, B.S., Prasad, K., Tomar, O.K. and Shurpali, N.J. (2000). Yield trends, and changes in soil organic-C and available NPK in a long-term rice wheat system under integrated use of manures and fertilizers. Field Crops Research, 68, 219-246.

Yang, W., Peng, S., Laza, R.C., Visperas, R.M. and Dionisio-Sese, M.L. (2008). Yield gap analysis between dry and wet season rice crop grown under high-yielding management conditions. Agronomy Journal, 100(5), 13901395.

Yoshida, S. (1981). Fundamentals of Rice Crop Science. International Rice Research Institute, Lo33s Banos, Philippines.

Yoshida, S. and Coronel, V. (1976). Nitrogen nutrition, leaf resistance, and leaf photosynthetic rate of the rice plant. Soil Science and Plant Nutrition, 22(2), 207-211.

Zhang, W. and M. Kokubun. (2004). Historical changes in grain yield and photosynthesis rate of rice cultivars released in the 20th century in Tohoku region. Plant Production Science, 7, 3644. 